\title{
Kernos
}

Revue internationale et pluridisciplinaire de religion grecque antique

$11 \mid 1998$

Varia

\section{Aphrodite Ourania of the Bosporus: The Great Goddess of a Frontier Pantheon}

\section{Yulia Ustinova}

\section{(2) OpenEdition \\ Journals}

Electronic version

URL: http://journals.openedition.org/kernos/1228

DOI: 10.4000/kernos. 1228

ISSN: 2034-7871

\section{Publisher}

Centre international d'étude de la religion grecque antique

\section{Printed version}

Date of publication: 1 January 1998

ISSN: 0776-3824

\section{Electronic reference}

Yulia Ustinova, "Aphrodite Ourania of the Bosporus: The Great Goddess of a Frontier Pantheon », Kernos [Online], 11 | 1998, Online since 21 April 2011, connection on 20 April 2019. URL : http:// journals.openedition.org/kernos/1228; DOI : 10.4000/kernos.1228 


\section{Aphrodite Ourania of the Bosporus: The Great Goddess of a Frontier Pantheon ${ }^{1}$}

\section{Introduction}

When coming to new places, Greek colonists usually brought with them their ancestral gods. In contrast, the pantheon of the Cimmerian Bosporus differed substantially from that of the metropoleis of the Bosporan cities, Miletus and Teos. In fact, the interaction between Greeks and local Iranianspeaking peoples (Scythians, Sindians and Maeotians), which started in the late seventh century BC, made this frontier area a melting pot of Greek and indigenous cultures. ${ }^{2}$ Local Iranian beliefs, mythology and cults had a considerable impact on the Bosporan religion. ${ }^{3}$ Indigenous cults influenced the shaping of the Bosporan pantheon, and especially the emergence and evolution of the cult of Aphrodite Ourania.

From the beginning of its colonization by the Greeks to the end of the ancient epoch Aphrodite Ourania was the Great Goddess of the Bosporus. In the first centuries $\mathrm{AD}$ she was the tutelary goddess of the Bosporus, the guardian of its kings and their subjects, grantor of power and victory in battle, the supreme cosmic deity of this world and the protectress of the dead in the nether world, and a great fertility-goddess, reigning the vegetal and animal kingdoms. ${ }^{4}$

1 This and related subjects are treated in detail in my forthcoming book The Supreme Gods of the Bosporus: Celestial Apbrodite and the Most High God (E.J. Brill Ed.).

2 For the history and archeology of the Bosporus see V.F. Gajdukevič, Das Bosporianische Reich, Berlin-Amsterdam, 1971.

3 The only comprehensive study of the subject is the Ph.D. dissertation by I.Y. SHaub: Kul'ty $i$ Religioznye predstavleniya naseleniya Bospora VI-IV vekou do n.e. [Cults and religious beliefs of the population of the Bosporus in the sixth-fourth centuries $\mathrm{BCl}$, Leningrad, 1987. I am grateful to I,Y. Shaub for his kind permission to cite this unpublished work.

4 Evidence of various aspects of this cult is abundant, but its survey is beyond the limits of the present work. However, epigraphic and numismatic data alone are sufficient to demonstrate Aphrodite's incontestable pre-eminence: V.V. STruve et al. (eds.), Corpus Inscriptionum Regni Bosporani, Moscow-Leningrad, 1965 (hereafter CIRB), Nos. 31, 35, 976, 1005, 1045, 1055, 1115, 1237; N.A. Frolova, The Coinage of the Kingdom of Bosporus. AD 69-238, Oxford, 1979 (BAR International Series, 56), passim. 


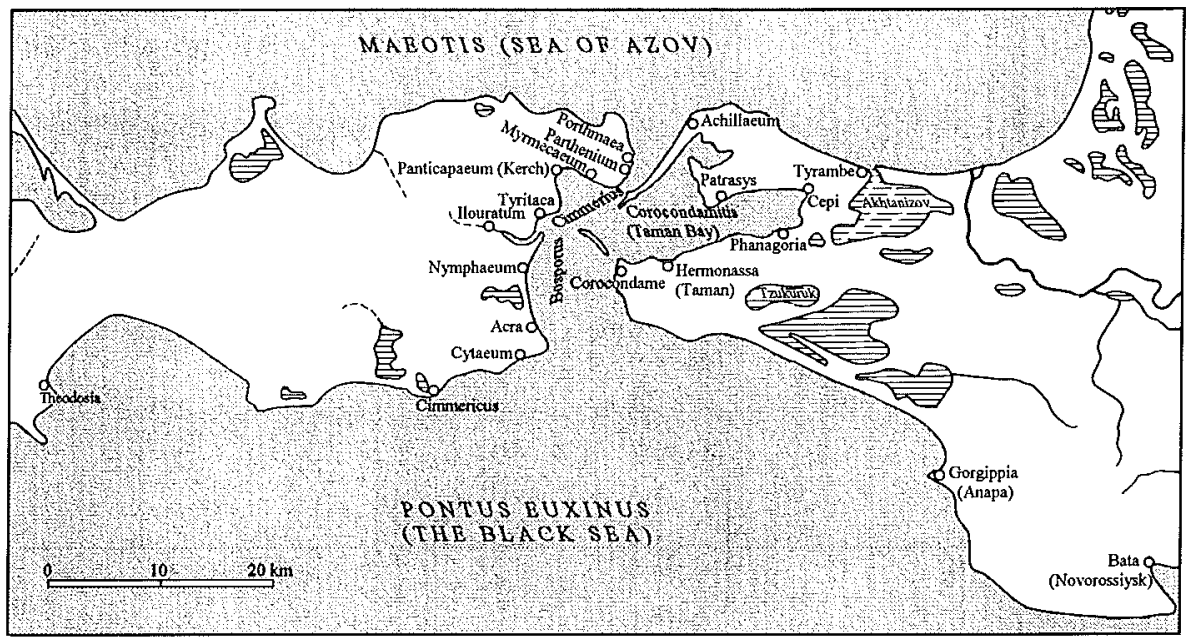

Map. 1

This majestic divinity evolved as an amalgamation of two goddesses who bore the same Greek name, Aphrodite Ourania: Aphrodite Ourania, the Mistress of Apatourum, worshipped by the Greeks of the area almost from the onset of their settlement on the shores of the Bosporan strait in the early sixth century BC; and Argimpasa, the native Great Goddess, who was identified with Aphrodite Ourania both by the Greeks and by the indigenous peoples themselves. However, in the first centuries $\mathrm{AD}$, the Bosporan kingdom underwent profound Iranization, ${ }^{5}$ as a result of a massive influx of Iranian-speaking Scythians and Sarmatians into its population. This Iranization, apparent in every sphere, may easily account for numerous nonGreek traits in the Bosporan cult of Aphrodite Ourania during the Imperial period. Yet influence of indigenous population on Bosporan culture is apparent already in the sixth-fourth centuries BC. ${ }^{6}$ During this early period of the Bosporan history local traits were already conspicuous in the cult of Aphrodite Ourania. The object of the present paper is two-fold: to demonstrate that Aphrodite dominated the Bosporan pantheon, and that her early cult emerged under local, Scythian and Sindo-Maeotian influence.

5 The term was coined by M.I. Rostovtzev (e.g. M. RostovtzefF, Queen Dynamis of Bosportus, in JHS, 39 [1919], p. 109).

6 Gajdukevič, op. cit. (n. 2), p. 65-96; Y.G. Vinogradov, Nekotorye diskussionnye problemy grecheskoy kolonizatzii Bospora Kimmeriyskogo [Some debatable problems of the Greek colonization of the Cimmerian Bosporus], in VDI, 3 (1995), p. 152-160. 


\section{Aphrodite of Apatourum}

Prior to the third century BC the cult of Aphrodite is attested epigraphically neither in Miletus, the metropolis of Panticapaeum and most other colonies of the Bosporus, nor in Teos, the metropolis of Phanagoria. ${ }^{7}$ The stimulus for the emergence of this cult on the Bosporus, and especially on the Asiatic shore, is thus to be sought in the impact of a local tradition, that made itself felt already at the early stages of the evolution of the cult.

Apatourum is the name of a famous sanctuary of Aphrodite Ourania, which was situated on the Asiatic side of the Bosporus. The exact location of the sanctuary is still disputed. ${ }^{8}$ Literary tradition relates its foundation to the sixth century $\mathrm{BC}$, when it was established on a shore of a small harbor, which was also called Apatourum (Hecat. apud Steph. Byz., s.v. 'A $\pi$ ó $\tau o v \rho o v ;$ Strabo, XI, 2; 10; Plin., Hist. Nat., VI, 6, 18). Aphrodite Ourania, the mistress. of Apatourum, was also worshipped in the European Bosporus. Her official

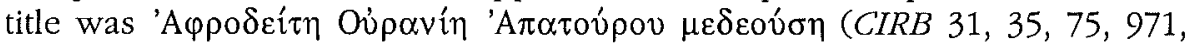
1111).

Ourania as an epiclesis of Aphrodite was common all over the Greek world, and indicated an emphasis on the Oriental connections of the goddess. ${ }^{9}$ Aphrodite Ourania was the Greek counterpart of the Phoenician Queen of Heavens. Ancient writers (e.g. Hdt., I, 105; Paus., I, 14, 7; III, 23, 1) were aware of the Levantine origin of the cult. The Greek cult of Aphrodite Ourania has been recently exhaustively treated by Vinciane PirenneDelforge. ${ }^{10}$

The word Apatouros was incomprehensible for Greeks, who therefore invented for it a false etymology resting on a phonetically similar Greek word and a local legend. Strabo (XI, 2, 10)' cites this legend:

Those who seek the real meaning of the epithet of the goddess, adduce a certain myth, according to which when she was attacked there by the Giants, she called upon Heracles and concealed him in a hiding place; and then, introducing the Giants one by one, gave them over to Heracles to be murdered through treachery ( $\dot{\xi} \xi \dot{\alpha} \pi \alpha \dot{\alpha} \tau \zeta$; translation by H.L. Jones, modified).

7 N. Ehrhardt, Milet und seine Kolonie, Frankfurt am Main, 1983, p. 164; W. Ruge, Teos, in $R E$, V A 1 (1934), col. 539-570.

8 For the discussion see S.R. TokHTAs'yev, Apatur. Istoria Bosporskogo suyatilishcha Afrodity Uranii [Apatourum. A history of the Bosporan shrine of Aphrodite Ourania], in VDI, 2 (1986), p. 138-145.

9 W. Fauth, Apbrodite, in Kleine Pauly, I (1964), p. 425-431; W. Burkert, Greek Religion, transl. by J. Raffan. Oxford, 1985, p. 152-156; W. BurkerT, The Orientalizing Revolution, transl. by M. E. Pinder and W. Burkert. Cambridge (Mass.), 1992, p. 95-100.

10 L'Apbrodite grecque, Athens-Liège, 1994 (Kernos, Suppl. 4). 
Since M.I. Rostovtzev, ${ }^{11}$ almost all the writers on the religion of the Black Sea region consider this story one of the Greek versions of the Scythian genealogical myth and use it as an important argument in favor of the close connections between Aphrodite Apatouros and the local Scytho-Maeotian goddess. ${ }^{12}$ In fact, Herodotus (IV, 8-10) relates a myth about Heracles and the monstrous sovereign of Scythia, half-woman and half-snake, who lived in a cave, stole the cattle of Geryoneus from the hero, and afterwards bore him three sons. One of these sons was destined to become the ancestor of the Scythian royal dynasty. Other versions of the same myth are recorded by Valerius Flaccus (VI, 48-59), Diodorus (II, 43) and in the Tabula Albana (IG, XIV, 1293 A 93 f.). Those who draw the two legends together base their opinion on the fact that in both Heracles and the local female deity are the protagonists; Heracles has to fight monsters; Aphrodite as well as the anguipede goddess dwell in a cave. We shall return to this goddess further on.

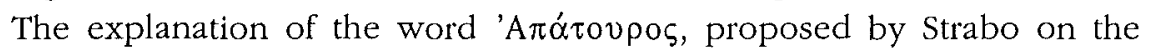
behalf of the Bosporan Greeks, is curious, but misleading. No less deceptive is the conviction of some modern scholars that the cult of Aphrodite 'A $\pi$ ó $\tau$ ov $\rho$ os emerged on the Bosporus under' the influence of the festival of 'A $\pi \alpha \tau o$ ópto, imported from the Ionian metropoleis of the Bosporan Greeks, ${ }^{13}$ From the point of view of the cult, the Ionian Apatouria were under the protection of Zeus, Athena and Apollo. ${ }^{14}$ Aphrodite Apatourias has never been worshipped outside the Bosporus. To be sure, the virgins of Troezen (Paus., II, 33, 1) celebrated the festival of Athena, and not Aphrodite Apatouria, as $\mathrm{H}$. Frisk and $\mathrm{P}$. Chantraine stated unanimously, but nevertheless erroneously. ${ }^{15}$ Joining the non-existent Aphrodite Apatouria of Troezen to the Bosporan Aphrodite Apatouros, both scholars maintained that

11 M. Rostovtzeff, Le culte de la Grande Déesse dans la Russie méridionale, in REG, 32 (1919), p. 473.

12 To cite only a few: M.I. ARTamonov, Antropomorfnye bozbestua $v$ religii skifov [Anthropomorphic deities in the Scythian religion], in Arkbeologicbeskiy sbornik Gosudarstvennogo Ermitazba [Proceedings in archaeology of the State Hermitage], 2 (1961), p. 65; I.I. Tolstoy, Chemomorskaya legenda o Gerakle i zmeyedeve [The Black Sea legend on Heracles and the Snake Maiden], in Stat'i o folklore [Articles on Folklore], Moscow-Leningrad, 1966, p. 236; D.S. RayevskiY, Ocberki ideologii skifo-sakskikh plemen [Essays on the ideology of the Scytho-Saka tribes], Moscow, 1977, p. 56; SHaub, op. cit. (n. 3), p. 93.

13 L.R. Farnell, The Cults of Greek States, Oxford, 1896-1909, vol, 2, p. 657; L.P. Kнагко, Kul't Afrodity na Bospore Kimmeriyskom [The cult of Aphrodite on the Cimmerian Bosporos], in Kratkiye Soobsbcheniya Instituta Istorii Material'noy Kul'tury $A N$ SSSR [Short communications of the Institute of the Hisory of Material Culture of the Academy of Sciences of the USSR], 13 (1946), p. 138; GAjDukEvič, op. cit. (n. 2), p. 226.

14 L. Deubner, Attische Feste, Berlin, 1932, p. 232-234; H.W. PARKE, Festivals of the Atbenians, London, 1977 , p. 88-92.

15 H. Frisk, Griechische etymologisches Wörterbuch, Heidelberg, 1959, vol. 1, p. 118; P. Chantraine, Dictionnaire étymologique de la langue grecque, Paris, 1968, vol. 1, p. 96. 
'A $\pi \alpha$ '́ovpos as an epiclesis of Aphrodite was a derivation from 'A $\pi \alpha \tau o v ́ p \imath \alpha$. Aphrodite Apatouros however has nothing to do with the Apatouria; furthermore, her full title during eight hundred years remained 'A $\varphi \rho \circ \delta \varepsilon i \tau \eta$

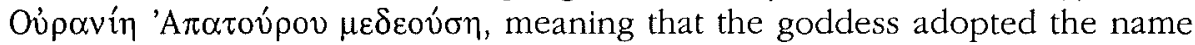
of the place, and that it is the toponymic which requires an explanation. In fact, even the ancient Greeks did not suggest that Apatouros was linked with Apatouria, although this association would have been more apparent than the complicated story of $\alpha \dot{\alpha} \alpha \dot{\tau} \eta$.

The etymology of the word 'A ád ovpos is not Greek, and is to be sought in the local languages. This word is a composite of two Iranian stems, which appear in the glossary of Scythian word stems by V.I. Abayev, ${ }^{16}$ ap-meaning "water", and tura - "quick" or "mighty". Thus, Apatourum may be rendered as "mighty water" or "quick water". Both stems were used in the formation of hydronymics, ${ }^{17}$ and it looks natural that together they designated a harbor and hence a local cultic place, where the indigenous Great Goddess had probably been venerated before the Greeks arrived. On the other hand, one can easily expect a goddess, such as Aphrodite or Astarte, known to be associated with the aquatic element, to become a mistress of "mighty waters."

The word Apatouros therefore appears to be of local origin, and in the place thus named the local goddess had been worshipped before the Greek colonization. The goddess was famous enough for the first colonists to learn about her shortly after their arrival to the Bosporus. They associated her with Aphrodite Ourania they knew and established her first Greek shrine, presumably in the ancient cultic place.

\section{The Local Great Goddess}

The local cult of a Great Goddess was a very complex phenomenon, a blend of Levantine, Iranian, and other elements. Herodotus (IV, 59) identifies the Scythian goddess Argimpasa ${ }^{18}$ with Aphrodite Ourania. He also records $(I V, 67)$ that Scythian non-traditional prophets were Enareis oi $\alpha v \delta \rho o ́ \gamma v v o r$, who maintained that Aphrodite endowed them with the prophetic capacities. Scythians believed that Aphrodite also punished the Enareis with a

16 In his book Osetinskiy yazyk i folklor [Ossetian language and folklore], Moscow, 1949 , p. $153,185$.

17 The former stem is evident in several personal names; in the form apra- (deep water) it is present in the hydronym $\Delta \alpha$ '́ $\alpha \pi \rho i \varsigma$ - Dnieper (deep river) (ABAYEv, op. cit.

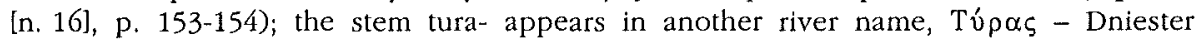
(ABAYEv, op. cit. [n. 16], p. 185).

18 For the etymology and the correct form of the name see M. VASmer, Die Iranier in Südrussland. Untersuchungen über die ältesten Wobnsitze der Slaven, Leipzig, 1923, p. 1112; ABAyEv, op. cit. (n. 16), p. 176; G. WIDENGREN, Die Religionen Irans, Stuttgart, 1965, p. 160 . 


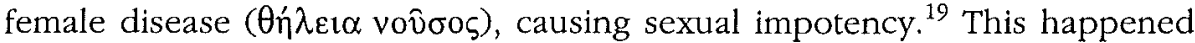
during the Scythian occupation of Asia, when some of them plundered the highly venerated sanctuary of Aphrodite Ourania in Ascalon, in Palestine (Hdt., I, 105). ${ }^{20}$

The transvestite transsexuality of these eunuchs ${ }^{21}$ fits very well the cult of the Levantine Aphrodite Ourania, which reveals many features of androgyny (Philochor., 328 F 184 Jacoby; Macrob., Sat., III, 3, 2; Plut., Thes., 18). ${ }^{22}$ It is therefore only natural that Greek travelers, observing the strange Scythian custom, deemed it appropriate to associate it with the familiar practice of eunuchs in service of a goddess. ${ }^{23}$ In fact, Pausanias (I, 14, 7) maintained that the cult of Aphrodite Ourania was established in Attica by Aegaeus who thought that his childlessness was a result of the goddess' anger.

The Scythian Argimpasa was certainly not completely identical with Aphrodite of Ascalon, but for Greeks in general and for Herodotus in particular both of them were Aphrodite Ourania. Moreover, numerous Greekstyle (and usually Greek-made) representations of Aphrodite and Eros which were discovered in indigenous complexes of indisputable cultic nature, such as tombs, ${ }^{24}$ indicate that the image of Aphrodite was meaningful to the

19 This "female sickness" is also described by Pseudo-Hippocrates (De aer., 22).

20 Since Scythians served in Nebuchadnezzar's army, which destroyed Ascalon in 604 $\mathrm{BC}$, it is possible that Herodotus described an episode of this campaign (L.E. STAGER, Asbkelon, in E. STERN (ed.), The New Encyclopaedia of Archaeological Excavations in the Holy Land, vol. I, New York-London-Toronto, 1992, p. 104). For the expeditions of Scythians to Asia Minor and their stay there see I.M. Diakonoff, Media, in The Cambridge History of Iran, II (1985), p. 89-109.

21 For this phenomenon see W.R. HAlliday, A Note on the $\theta$ indela vovoos of the Scytbians, in ABSA, 17 (1910/11), p. 95-102; K. Meul, Scytbica, in Hermes, 70 (1935), p. 121-176; G. DumÉzil, Les 'énarées' scytbiques et la grossesse du Narte Hamyc, in Latomus, 5, 3/4 (1946), p. 249-255; T. TAYlor, The Prebistory of Sex, London, 1996, p. 211214.

2 M. Delcourt, Hermaphrodite, Mythes et rites de la bisexualité dans l'antiquité classique Paris, 1958; H. Herter, Die Ursprünge des Apbroditekultus, in Éléments orientaux dans la religion grecque ancienne, Paris, 1960 (Travaux du Centre d'études supérieures spécialisé d'bistoire des religions de Strasbourg), p. 71-75; BuR KERT, Greek Religion, cit. (n. 9), p. 152, 155. For the double gender of Inanna-Ishtar-Astarte see J. Flemberg, Venus Armata. Studien zur bewaffneten Apbrodite in der griecbiscb-römischen Kunst, Stockholm, 1991 (Acta Instituti Atbeniensis Regni Sueciae, Series in 8\%, 10), p. 13-14; cf. B. Groneberg, Die sumerisch-akkadische Inanna/Istar: Hermapbroditos?, in Die Welt des Orients, 17 (1986), p. 25-46.

23 Halliday, art. cit. (n. 21), p. 99.

24 Such monuments are too numerous to be cited here. One of the most interesting and sumptuous examples is the famous Bol'shaya Bliznitza tumulus: B. Minns, Scytbians and Greeks, Cambridge, 1913, p. 422-429; GajDukevič, op. cit. (n. 2), p. 296-300. For the interpretation of this complex see I.Y. SHAUB, Pogrebeniya kurgana Bol'sbaya Bliznitza kak istochnik po istorii religioznykh predstavleniy zhiteley Bosporskogo tzarstua [The Burials of Bol'shaya Bliznitza tumulus as a source for the history of religious beliefs of 
Scythians, that is, they linked it with their own conceptions, most probably, with their belief in Argimpasa-Aphrodite. Hence the Scythians of Herodotus' age, who regarded the "female disease" of the Enareis as a result of Aphrodite's wrath, were aware of the identity of this Aphrodite with their Argimpasa. It should be also observed that the goddess, whose image decorated the garments of deceased and appeared on objects intended for interment in burials, was manifestly chthonic.

The peculiarity of the Ascalon cult of Aphrodite Ourania is noteworthy. This ancient sanctuary of the goddess, the most ancient in Herodotus' opinion (I, 105), continued to be venerated during the later epochs. The equation of Aphrodite Ourania of Ascalon with the Semitic Astarte is beyond doubt. ${ }^{25}$ Astarte, it should be mentioned, was believed to change men into women and women into men, ${ }^{26}$ which is also a distinctive feature of the Ascalonian goddess.

Another relevant aspect is the role of a semi-bestial creature, subordinate to Argimpasa-Aphrodite Ourania. In Ascalon, the cult of pisciform Derceto ${ }^{27}$ was linked with the cult of Aphrodite. That Aphrodite-Astarte of Ascalon was considered implacable to those who insulted her, illustrates not only the example of Enareis, but also the tragic story of Derceto, as recorded by Diodorus (II, 4, 3): Derceto, having offended Aphrodite, suffered a great shame and grief, and ultimately threw herself into a deep lake near Ascalon, transformed into a fish, and only her head remained that of a woman

Fig. 1. 1. Gable of the stele with a dedication of a thiasos to Aphrodite Ourania Apatourou medeousa (CIRB 75). From VALDGauer, art. cit. (n. 54), fig. 4.; 2. Gable of a stele from Batareyka II site. Limestone. From Sokol'skiy, Fragment..., p. 129; 3. Gold pendant from the Kul'-Oba tumulus. From D.B. Shelov, K voprosu o vzaimodeystvii grecheskikb $i$ mestnykh kul'tov $v$ Severnom Prichemomor'ye [On the interaction between Greek and local cults on the Northern Black Sea littorall, in Kratkiye Soobshcheniya Instituta Istorii Material'noy Kul'tury AN SSSR [Short communications of the Institute of the History of Material Culture of the Academy of Sciences of the USSR], 34 (1950), fig, 18: $1 ;$ 4. The forepiece of the horse harness from the Tzymbalova Mogila tumulus. From D.S. RaYevsKiY, Model' mira skifskoy kul'tury (The world model of the Scythian culture], Moscow, 1985, p. 172; 5. Sarcophagus from the Taman peninsula: the gable. From Minns, op. cit., fig. 234.; 6. Gold pendant from the Chertomlyk tumulus. From RayevskiY, Ocberki..., fig. 8.; 7. Temple-pendants ("earrings") from the Lyubimovskiy tumulus. From Bessonova, op. cit., fig 16: 2 .

the inhabitants of the Bosporan Kingdom], in Kratkiye Soobsbcbeniya Instituta Arkbeo$\log$ ii AN SSSR [Short communications of the Institute of Archaeology of the Academy of Sciences of the USSR], 191 (1987), p. 27-33.

25 E. SCHürer, The History of the Jewish People in the Age of Jesus Christ (175 BC-AD 135), A new English version. Eds. G. Vermes, F. Millar and M. Blade, Edinburgh, 1979, vol. 2 , p. 31.

26 Flemberg, op. cit. (n. 22), p. 14.

27 For Derceto-Atargatis, Dea Syria, who was portrayed with fish and had sacred pools with fish in her cultic centers, see M. HökIg, Dea Syria-Atargatis, in ANRW, II, 17.3 (1984), p. 1536-1581. 

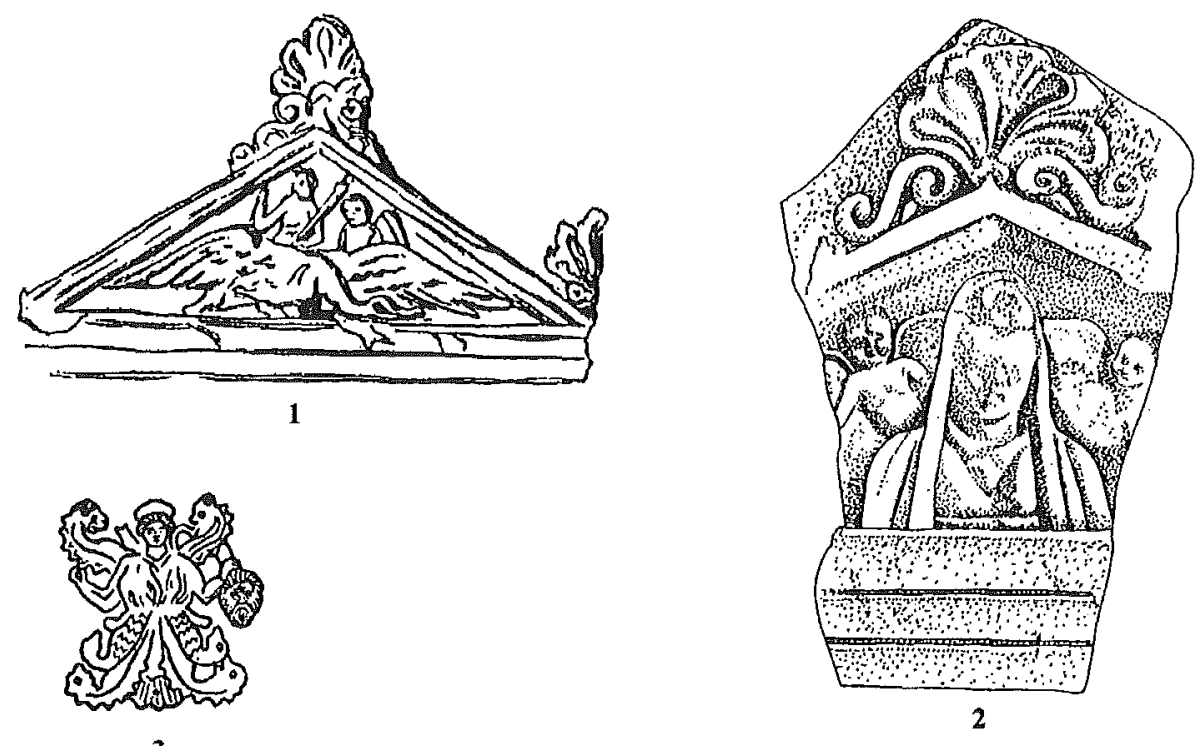

3
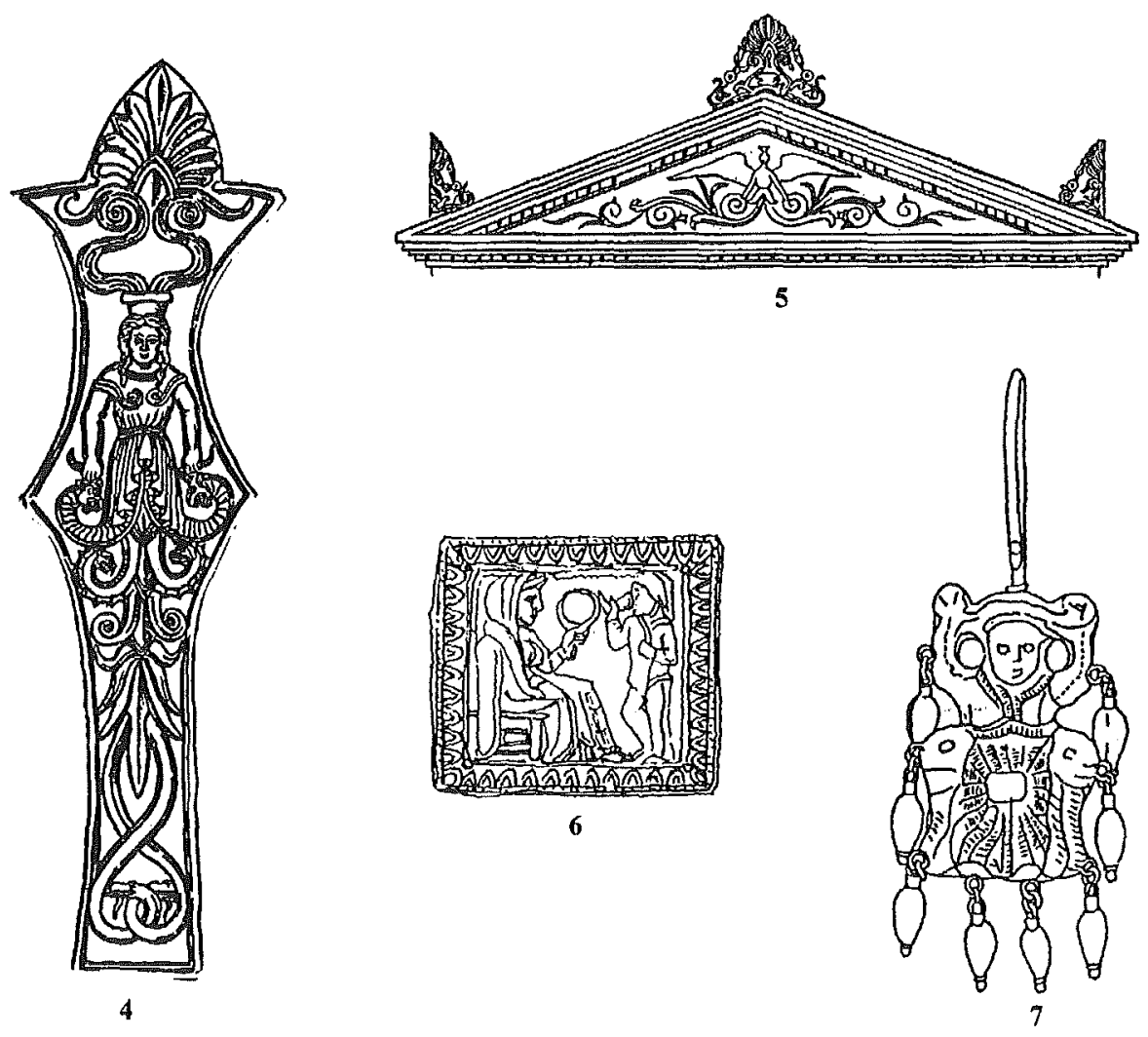
It is curious both that Herodotus did not refer to this distinguished goddess and her temenos, and that Diodorus failed to mention the famous Ascalon sanctuary of Aphrodite, who played such a remarkable role in the story. Hence probably there was one sanctuary, where one deity was worshipped, disguised under several names. In fact, doves, sacred to Derceto (Diod., II, 4, 4-6) and represented on the coins of Ascalon, ${ }^{28}$ belonged to AstarteAphrodite par excellence. The sea-born Aphrodite (Hes., Theog., 188), was no less at home in the water than the fish-like Derceto. Both goddesses were represented surrounded by dolphins. ${ }^{29}$ In Ascalon Derceto, an Aramaic deity, was presumably a later development of the Philistine Astarte. ${ }^{30}$

This merging of Aphrodite-Astarte-Derceto at Ascalon is very significant in the definition of Argimpasa's character as a vegetation-fertility goddess with clear androgynic traits, emphasizing her obvious Levantine connections. Another meaningful aspect is the possible congruity of the images of fishshaped Derceto and the anguipede Scythian foremother, mentioned above.

The pairing of a great and a minor goddess, the latter only semi-human, is known elsewhere: in Ephesos, Aphrodisias, and other cultic centers, where Great Goddesses was worshipped, a female creature with tendril-shaped legs also appeared. ${ }^{31}$ This splitting of the fertility-vegetation deity into two figures, one of them august and entirely anthropomorphic, and the second one semibestial, existed also in the Scytho-Maeotian religion. The image of the snakelimbed or tendril-limbed foremother was one of the most popular designs in Scythian art (e.g. fig. 1: 3, 4) ${ }^{32}$ Depictions of the anguipede goddess, represented as a mistress of animals and a vegetation deity, were usually found in the same burials, where objects portraying Aphrodite were unearthed. Taking into consideration the adoption of some major features of Argimpasa from the Anatolian-Levantine goddesses, it seems reasonable that the duality of the great mistresses of Near Eastern and Anatolian temples have prompted the affiliation of Argimpasa with the anguipede goddess in

28 L. ROBERT, Les colombes d'Anastase et autres volatiles, in JS (1971), p. 96.

29 J. Ferguson, The Religions of the Roman Empire, London, 1982, p. 19.

30 SCHÜrER, op. cit. (n. 25), p. 32.

31 Only a few of much more numerous examples may be cited here: Cyprus (L. Curtius, Torso, Stuttgart, 1958, p. 195, fig. 28); Ephesos, statues of Artemis the Colossal and Artemis the Beautiful; temple of Hadrian; Aphrodisias, Hadrianic baths (J.M.C. Toynbee, J.B. Ward Perkins, Peopled Scrolls: a Hellenistic Motif in Imperial Art, in Papers of the British School at Rome, 18 [1950], p. 31); propylaea of Aphrodite's temenos (F. Laumonier, Les cultes indigènes de Carie, Paris, 1958, p. 482); Magnesia, Artemision (C. Humann, H. Kонте, C. Watzinger, Magnesia am Mäander, Berlin, 1904, figs. 57, 60, 65, 69).

32 M. Rostovtzeff, Iranians and Greeks in Soutb Russia, Oxford, 1922, p. 107; A.P. IVANOVA, Mestnye elementy $v$ dekorativnoy skul'pture Bospora [Local elements in the Bosporan decorative sculpturel, in Sovetskaya Arkbeologiya [Soviet archaeology], 15 (1951), p. 188-203; RAyevskiY, op. cit. (n. 12), p. 52-53; S.S. Bessonova, Religioznye predstavleniya skifov [Religious notions of the Scythians], Kiev, 1983, p. 93-98. 
South Russia. Yet the sound mythological tradition, cited above, demon strates, that in the South Russian steppes the anguipede goddess belonged to the local pantheon; in fact, she had been worshipped as the Scythian foremother long before artifacts with her representations began to be executed by Greek artisans for the indigenous aristocracy.

Scythians were exposed to the influence of Levantine and Anatolian cults during their prolonged stay in Asia Minor, when isolation from the homeland must have weakened their professed immunity (Hdt., IV, 76) to alien religion. The Ascalon episode was singled out by the Scythians themselves and Herodotus after them because of the outstanding fame of the sanctuary. It was the joint overwhelming power of the great cults of the Levantine goddesses that subdued the Scythians and made them acknowledge it in the image of their Argimpasa-Aphrodite.

The Scythian Argimpasa, as mentioned earlier, must have also had Iranian roots. Iranians worshipped Anahita, the patroness of husbandry and fertility, the mistress of celestial waters. The permanent triple title of the goddess in the Avesta, Aredvi Sura Anahita, the Humid, Strong and Immaculate, signifies her synthetic nature. The goddess was multivalent, representing three functions: sovereignty (the Strong), priestly force (the Pure), and fecundity (the Humid). ${ }^{33}$ It was to Anahita that the warriors in the Avesta addressed their requests to grant them victory in battle (Aban Yast, XI, 42; I, 53-54; XV, 58; XVII, 69), ${ }^{34}$ and to her a great Armenian king offered severed heads of defeated enemies after one of his important victories. ${ }^{35}$ Anahita appears as a granter of sovereignty and glory (Aban Yast, XII, 46; XIII, 50), and is portrayed in various media handing investiture crowns to kings. ${ }^{36}$

All of these functions are present in the image of the indigenous goddess, the Scythian Argimpasa. She was also remarkably belligerent and cruel ${ }^{37}$ her anguipede companion was not infrequently depicted brandishing a severed human head (fig. 1: 3). ${ }^{38}$ By the fourth century BC Argimpasa-Aphrodite

33 For the cult of Anahita see WIDEngren, op cit. (n. 18), p. 19; M. BoYce, Anabid: Ardwisur Anabid. Anaitis, in E. Yarshater (ed.), Encyclopaedia Iranica, London-Boston, 1985, vol. 1, p. 1003-1006; M.-L. Chaumont, Le culte de la déesse Anabita (Anabit) dans la religion des monarques d'Iran et d'Arménie au $I^{\text {er }}$ siècle de notre ère, in Journal Asiatique, 235 (1965), p. 167-181; M.-L. Chaunont, Anabid: The Cult and Its Diffusion, in Encyclopaedia Iranica, London-Boston, 1985, vol. 1, p. 1006-1009

34 Cf. Bessonova, op. cit. (n. 32), p. 39; Boyce, art. cit. (n. 33), p. 1003.

35 Chaumont, Le culte de la déesse Anabita..., cit. (n. 33), p. 172.

36 WIDENGREN, op. cit. (n. 18), p. 319; R. GHIRShMAN, L'Iran des origines à l'Tslam, Paris, 1976, p. 260. London, 1962: fig. 218; C. ColPE, Development of Religious Thought, in The Cambridge History of Iran, 3 (1983), p. 846; CHAumont, Anabid..., cit. (n. 33), p. 1007-1008

37 Rostovtzeff, Le culte de la Grande Déesse..., cit. (n. 11), p. 469; Shaub, Kul'ty $i$ religioznye..., cit. (n. 3), p. 160-162.

38 Bessonova, op. cit. (n. 32), p. 98. The cult of severed human head is also attested archeologically: a mutilated head was discovered placed on an altar in the semi- 
Ourania turned into the divine patroness of Scythian royal dynasties, a development reflected mainly in iconographic evidence. ${ }^{39}$

\section{Epigraphic and Archaeological Evidence of the Aphro- dite Ourania Cult on the Bosporus}

The most ancient, early fifth-century inscription containing the word АПАТОРО is problematic: it has not been preserved and is known only by an eighteenth-century engraving (CIRB 1234). There is much more epigraphic evidence from the fourth century, most dedications to Aphrodite Ourania Apatourou medeousa coming from the Asiatic Bosporus (CIRB 971, 972, 1041). There are also dedications to Aphrodite from Panticapaeum (CIRB 7 , 13, 17).

A damaged double herm (CIRB 1111) with a dedication to Aphrodite Ourania Apatourou medeousa, found near Hermonassa, was set up in the early fourth century BC. Since the double herm is an offering to Aphrodite, one of its two faces must have been that of the goddess. This double herm has no exact parallels. However, herms of Aphrodite are attested archaeologically on the Bosporus. ${ }^{40}$ The practice of placing side-by-side herms of Aphrodite and a male deity was also well-known there, and a number of terracottas portray Aphrodite seated near male herms (fig. 3). ${ }^{41}$

The use of the herm indicates the chthonic nature of the cult. ${ }^{42}$ Chthonic symbolism of the herms has an interesting parallel in the depictions of the anodos of Aphrodite and of her protomae in the painting on a number of socalled Kerch-style vases, which were discovered in Panticapaeum (present day Kerch) and its vicinity, mostly in tombs, and seem to have been executed in compliance with Bosporan tastes and beliefs. ${ }^{43}$ The chthonic aspect in the cult of Aphrodite is also expressed in burial practices: numerous representations of the goddess herself or Eros, mainly terracottas, but also pieces of jewelry, were deposited in tombs. In addition, Eros holding a garland of

Sarmatian fortress of Ilouratum: A.D. GRACH, K voprosu o pozdnem etape "Tauro-skifskikb" religioznykh predstavleniy [On the late stage of the "Tauro-Scythian" religious notions], in Sovetskaya Etnographiya [Soviet anthropology], 4 (1952), p. 174-181.

39 Bessonova, op. cit. (n. 32), p. 40.

40 G. Kieseritzky, C. Watzinger, Griechiscbe Grabreliefs aus Südrussland, Berlin, 1909, pl. 28, fig. 407; cf. КнакКо, art. cit. (n. 13), p. 203-205.

41 M.M. Kobylina (ed.), Terrakoty Severnogo Prichernomor'ya - Suod arkbeologicheskikb istochnikou, Vol. G 1-11 [Terracottae of the Northern Black Sea littoral. Corpus of archaeological sources], Moscow, 1970 (parts 1-2), 1974 (parts 3-4); hereafter TSP 3: pl. 23. 2,$6 ; 25: 4,5 ; 26$.

42 A. Delivorrias, Apbrodite, in LIMC, II (1984), p. 2-151; SHaub, Kul'ty i Religioznye..., cit. (n. 3), p. 91.

43 H. Metzger, Les représentations dans la céramique attique du IV siècle, Paris, . 1951, p. 85; Shaub, Kul'ty i Religioznye..., cit. (n. 3), p. 99. 
flowers was represented on a mural in one of the Bosporan vaults (secondfirst centuries BC). ${ }^{44}$ The Greek Aphrodite appears to be scarcely related to the chthonic realm. ${ }^{45}$ Contrary to the common Greek practice, the Bosporan Aphrodite seems to be much more involved in the underworld beliefs, perhaps due to the local influence.

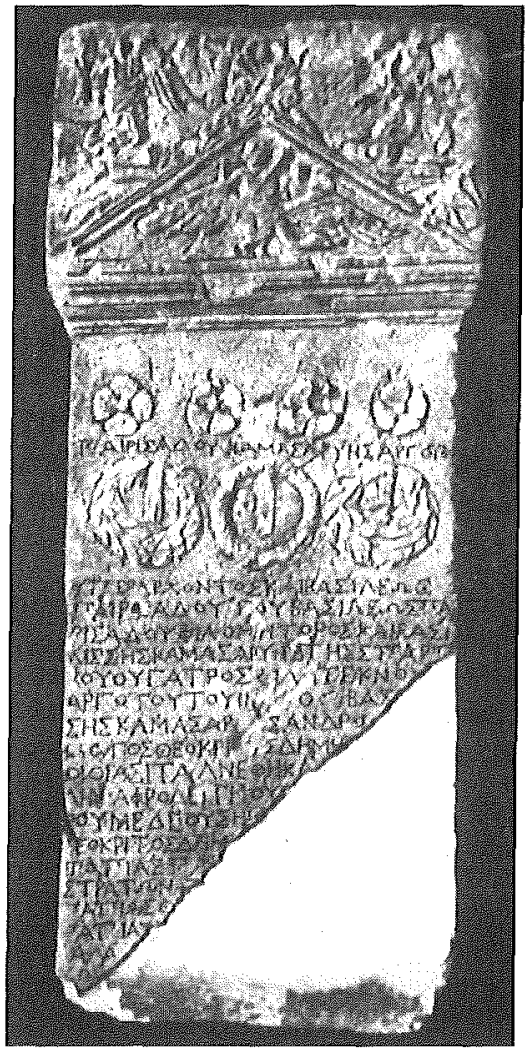

Fig. 2

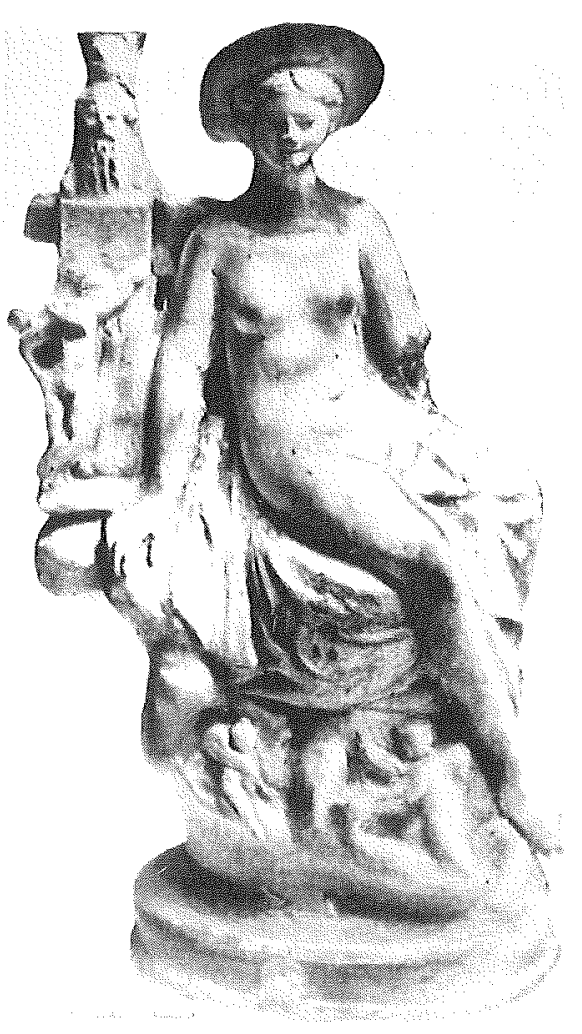

Fig. 3

Fig. 2. Stele with a dedication of a thiasos to Aphrodite Ourania Apatourou medeousa (CIRB 75). From Antichnye gosudarstua Severnogo Prichernomor'ya [Ancient states on the Northern Black Sea littorall, Eds. of the volume: G.A. Koshelenko, I.T. Kruglikova and V.S. Dolgorukov (No volume number) - Archeologiya SSSR [Archaeology of the USSR], B. A. Rybakov - ed. of the series, Moscow, 1984, pl, 121:2.

Fig. 3. Aphrodite seating near a herm. Terracotta. Late first century BC-first century AD. Panticapaeum. From TSP 3: pl. 26.

44 M.I. Rostov'tzev, Antichnaya dekoratiunaya zhivopis' na y'uge Rossii [Ancient decorative painting in South Russia], St. Petersburg, 1913-1914, vol. 1, p. 146, 149.

45 Pirenne-Delforge, op. cit. (n. 10), p. 442. 
Androgynic features in the Bosporan cult of Aphrodite, which are suggested by the double herm, are attested elsewhere by a number of literary sources. ${ }^{46}$ However, most conspicuously androgynous was the Scythian Aphrodite-Argimpasa.

Greeks adopted local iconographic motifs, as well. The most striking example is the depiction of the indigenous snake- or tendril-limbed goddess on Greek monuments, beginning from the fourth century $\mathrm{BC}$. The earliest example is a late fourth-century BC carved and inlaid wooden sarcophagus, discovered not far from Phanagoria (fig. 1: 5).

The appearance of the anguipede monster beside Aphrodite Ourania in the Greek cities of the Bosporus, as well as the emphasis on the chthonic aspect of Aphrodite and her androgyny, seem to be due to the impact of the indigenous beliefs.

Aphrodite's connection with the sea, an Oriental feature in her cult, ${ }^{47}$ is apparent in a mid-third century $\mathrm{BC}$ fresco, discovered in a sanctuary in Nymphaem. ${ }^{48}$ This wall-painting, depicting a fleet of over thirty ships, was covered with graffiti containing the name of Aphrodite. The earliest inscription attesting the nautical aspect in Aphrodite's personality is a first-century

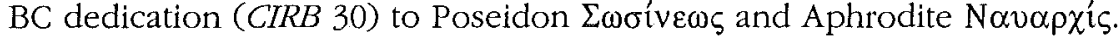

The existence and prosperity of a temple of Aphrodite in the Bosporan town named Gardens - Kin $\pi 01$ - is perhaps an additional indicator of the overall Oriental background of the cult of Aphrodite on the Bosporus. ${ }^{49}$ The sanctuary at Cepi was probably founded in the sixth century BC: the priest who inscribed his dedication on a late sixth-century $B C$ cylix, most likely served in the sanctuary of Aphrodite in the town. Archaeologically, a secondcentury $\mathrm{BC}$ temple in antis was identified as belonging to Aphrodite. ${ }^{50}$

In the course of the following centuries other sanctuaries of Aphrodite Ourania were founded. Regrettably, the Phanagorian sanctuary which is called "remarkable" by Strabo (XI, 2, 10) and which must have been the second in importance after" the Apatourum itself, has not been identified archaeologically. It is reasonable to presume that by the beginning of the fourth century $\mathrm{BC}$ the Phanagorean sanctuary had already been erected. Two

46 See above, note 20.

47 M.P. Nilsson, GGR, I3, 521 ; Burkert, Greek Religion, cit. (n. 9), p. 153; Flemberg, op. cit. (n. 22), p. 14-15.

48 N.L. GRACH, Otkrytiye novogo istoricheskogo pamyatnika $v$ Nimfeye [A discovery of a new historical monument in Nymphaeum], in VDI, 1 (1984), p. 81-88.

49 Cf. SHAub, Kul'ty $i$ Religioznye..., cit. (n. 3), p. 91. For the cult of Aphrodite in the Gardens, see E. Langlotz, Aphrodite in den Gärten, Heidelberg, 1954; Burkert, Greek Religion, cit. (n. 9), p. 153, Pirenne-Delforge, op. cit. (n. 10), p. 63-66, 342.

50 N.I. SokiL'skix, Suyatilishche Afrodity $v$ Kepakb [The sanctuary of Aphrodite in Cepi], in Sovetskaya Arkbeologiya [Soviet archacology], 4 (1964), p. 101-118, EhrHard, op. cit. (n. 7), p. 166. 
bases with dedications to Aphrodite Ourania Apatourou Medeousa (CIRB $971,972)$ are likely to originate from there.

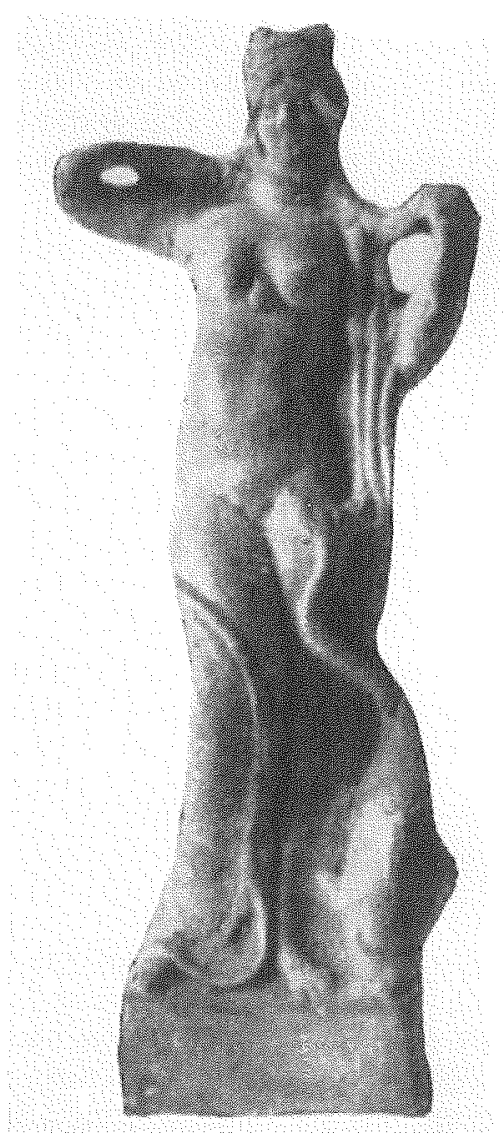

Fig. 4

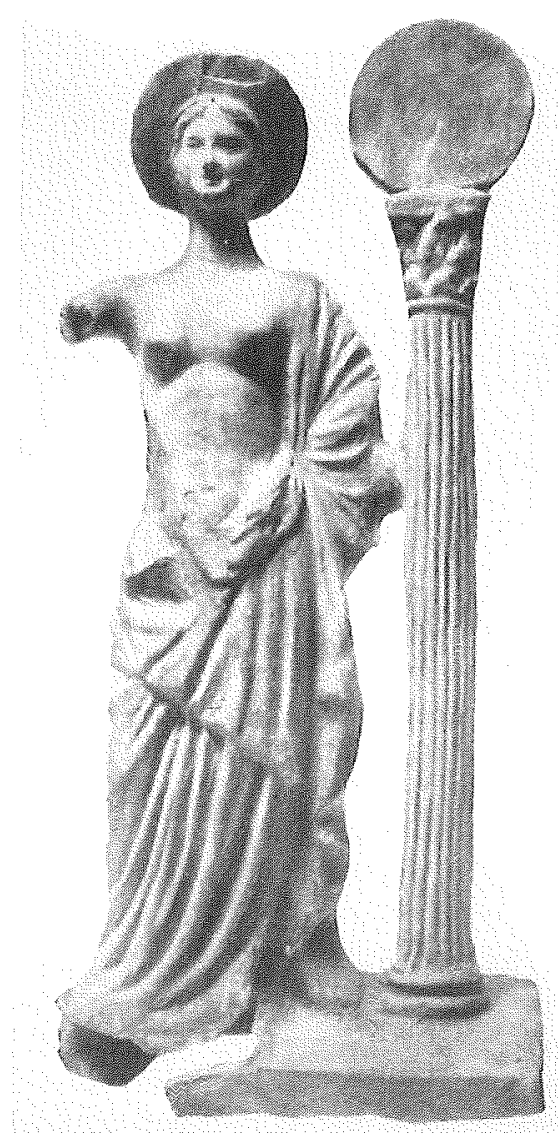

Fig. 5

Fig. 4. Aphrodite Anadyomene. Terracotta. First century BC. Panticapaeum. From TSP 3: pl. 23: 3.

Fig. 5. Aphrodite standing near a column topped with a sun disk. Terracotta. Second century BC. Panticapaeum. From TSP 3: pl. 22: 1.

Although no architectural remains of the early temples of Aphrodite have yet been discovered in the Bosporus, archaeological evidence is rather abundant. Quantitatively, the most important category is terracottas, either produced on the Bosporus or imported: Aphrodite with a dove; Aphrodite with Eros; protomae of Aphrodite. Terracottas of Aphrodite Anadyomene become common in the second century BC (fig. 4). Some figurines show nude Aphro- 
dite standing or sitting beside a herm (fig. 3). ${ }^{51}$ Depictions of Aphrodite herself and Eros are especially dominant among the locally made figurines. ${ }^{52}$

The cult of Aphrodite in the guise of Porne is suggested by the terracotta reliefs of Aphrodite with Eros tying up her sandal, all of them produced in Phanagoria; the same subject is depicted on a gold finger-ring from a Bosporan tumulus. ${ }^{53}$ The double nature of Aphrodite, both Pandemos and Ourania, is conveyed in her representation as Epitragia on a terracotta plaque. ${ }^{54}$ In her solar aspect, the goddess is represented on a second-century $\mathrm{BC}$ terracotta: the semi-nude goddess wearing a polos stands near a column which is crowned with the sun disk (fig. 5). ${ }^{55}$

Both iconographically and historically, one of the most important monuments of the cult of Aphrodite Ourania Apatourou medeousa is a secondcentury BC stele, topped with her image (figs. $1: 1 ; 2$ ). The stele bears a dedication of a thiasos to the goddess (CIRB 75). It was found in Panticapaeum and is therefore the first document with the full title of the goddess from the European Bosporus.

The gable decorating the stele features Aphrodite riding a swan and holding a scepter in her left hand, with Eros to her right. Above the cornice are two Nikae. Historically, this type of Aphrodite on a swan probably belongs to an artistic tradition going back to a popular Attic masterpiece of the fifth century $\mathrm{BC}$. It is quite likely that the sculptor of the Panticapaeum stele adopted the artistic and iconographic style of Ourania from some imported piece, such as ivory plaques, bronze mirrors, etc. ${ }^{56}$ However, it seems more convincing that he copied a local replica of the original Athenian statue. ${ }^{57}$

A Bosporan addition to the classical model was perhaps the representation of two Nikae above the gable, intended to convey the significance of Aphrodite Ourania as the bestower of military success. In this quality Aphrodite was worshipped elsewhere in the Greek world. ${ }^{58}$ The goddess'

51 E. g. TSP 3: pls. 7: 3, 4; 16:2; 23:1, 2, 3, 6; 25:4, 5; 26; 28: 8; 57: 5, 67: 4; TSP 4: pls. 19: 4; $38: 2,3,5,7,8 ; 41: 1$.

52 TSP 3: pls. 61, 62 .

53 I.D. Marchenko, O kul'te Afrodity na Tamani IOn the cult of Aphrodite in the Taman peninsula], in M.M. KовyLINA (ed.), Istoria $i$ kul'tura antichnogo mira [History and culture of the Ancient World], Moscow, 1977, p. 124-125; cf. Delivorrias, art. cit. (n. 42), no. 591; Pirenne-Delforge, op. cit. (n. 10), p. 60-62.

54 TSP 5: pl. 5. 5; O.F. VAldgauer, Afrodita Urania i Afrodita Pandemos [Aphrodite Ourania and Aphrodite Pandemosl, in Izvestiya Rossiyskoy Akademii Istorii Material'noy Kul'tury [Bulletin of the Russian Academy of the History of Material Culture], 2 (1922), p. 225; cf. Delivorrias, art. cit. (n. 42), p. 98-99; Pirenne-Delforge, op. cit. (n. 10), p. 34-40.

55 TSP 3: pl. 22. 1.

56 VALDGAUER, art. cit. (n. 54), p. 209-212; 217-219.

57 Cf. KHARKo, art. cit. (n. 13), 139.

58 Pirenne-Delforge, op. cit. (n. 10), p. 208-209, 450-454. 
bellicosity is usually explained as a manifestation of her Oriental parentage. ${ }^{59}$ However, the Scythian Aphrodite Ourania and the anguipede goddess were frighteningly bloodthirsty. On the Bosporus, belligerence of Aphrodite Ourania was especially emphasized during the first centuries AD.

The inscription on the stele commemorates its dedication by a thiasos:

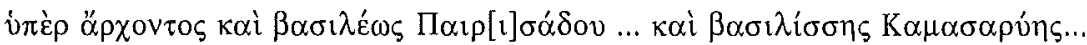

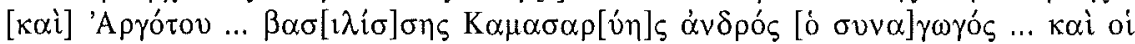

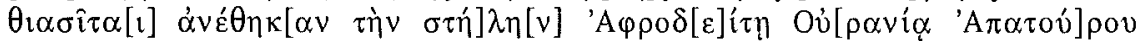

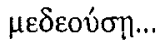

For the sake of the archon and king Pairisades ... and the queen Camasarye ... and Argotas, the husband of queen Camasarye, synagogos ... and the thiasotai offered the stele to Aphrodite Ourania Apatourou medeousa...

This is the earliest document left by a thiasos on the Bosporus. The striking peculiarity of the Bosporan thiasoi - their connection with the state cults and royal power - is already evident in this inscription. In fact, in the second century BC the cult of Aphrodite Ourania Apatourou medeousa had already gained an prominent status in the state. The first dedication to Aphrodite by a member of the royal family, performed in the fourth century $\mathrm{BC}$ (CIRB 1041), marked the beginning of the future devotion of the Bosporan kings to Aphrodite. ${ }^{60}$ The semi-barbarian Hellenized dynasty of Spartocids, which ruled the Bosporus from the mid-fifth to the late second century $\mathrm{BC}$, and to which king Pairisades and queen Camasarye belonged, maintained close connections with indigenous aristocracy. ${ }^{61}$ Noteworthy, the Scythian and Sindo-Maeotian counterparts of Aphrodite appear to have been patronesses of local kings and a grantors of royal power.

Alongside the iconographic theme of Aphrodite on the swan, another type, which persisted into the first centuries $A D$, appeared on a fragment of a Bosporan stele, dated to the second-first centuries BC (fig. 1: 2). ${ }^{62}$ It was discovered in one of the rural settlements of the Asiatic Bosporus. The preserved central part of its gable features a bust of the goddess, flanked by two Erotes.

The composition of Aphrodite flanked by two Erotes has no parallels in Hellenistic Bosporan sculpture, but appears repeatedly on metal pendants from the northern Black Sea littoral. As imported objects with this design are

59 W. Burkert, Homo Necans, Translated by P. Bing, Berkeley, 1983, p. 80; Flemberg, op. cit. (n. 22), p. 15-22.

60 Above, note 2.

61 Rostovtzeff, Le culte de la Grande Déesse..., cit. (n. 11), p. 97; Gajdukevič, op. cit. (n. 2), p. 65-96.

62 N.I. Sokol'sкix, Fragment stelys izobrazbeniem Afrodity [A fragment of stele with a representation of Aphrodite], in V.V. KRороткіN, Problemy sovetskoy arkbeologit [Problems in Soviet archaeology], Moscow, 1978, p. 128-132. 
extremely rare, these pendants seem to have been modeled on some Black Sea monument, most probably Bosporan, since it was on the Bosporus that the cult of Aphrodite occupied such a salient position. ${ }^{63}$ In any case, this particular image of Aphrodite was clearly created in accord with the Bosporan artistic conventions of the period: the rounded shape of the goddess' face and the treatment of her garments accurately reflect the local type, common in the reliefs on the gravestones. Thus, this iconographic type of Aphrodite corresponds much better both to the intrinsic local traits in the cult of the goddess and to the aesthetic taste of the Bosporan population. It is only natural that this type persisted during the later centuries, while the classical Aphrodite on the swan is represented by an isolated example.

By the fourth century $\mathrm{BC}$ there were probably several cultic statues of Aphrodite on the Bosporus. There are some forcible arguments in favor of this assertion. They rest on the discovery in Scythian and Sindo-Maeotian aristocratic burials of objects of art, executed by different artisans, showing representations of the goddess, which are very similar stylistically and were presumably modeled on the same Greek examples. Thus, the image of the seated goddess on the numerous gold pendants from several fourth-century BC tumuli (fig. 1: 6) may perhaps be traced back to a Bosporan monumental prototype. ${ }^{64}$ Three gold temple pendants (so-called "earrings", fig. 1: 7) from three tumuli of the same century, hundreds of kilometers apart, show the same hieratically stiff seated female figure with enormously large leaf-like palms raised to her head, that re-appears on the Bosporan monuments in the Roman period. Seated figures of this kind are extremely unusual in jewelry, but the posture is normal in monumental sculpture, and the Bosporus was a major center of the Northern Black Sea decorative metalwork, producing luxury goods for the barbaric market. It is very likely thus that the more skillfully executed version of the "earrings" had in fact been modeled on a Bosporan statue and was consequently reproduced on cruder replicas. ${ }^{65}$

\section{Summary}

Very early in the history of the Greek colonies on the Bosporus Aphrodite Apatouros was already one of the most venerated deities. In the cult of the goddess ostensible Levantine traits engaged with the local elements to produce a powerful divine personality, who attracted the devotion of royal

63 SOKOL'SKIY, ibid., p. 131.

64 A.P. Iwanowa, Gestalten der örtlichen Mytbologie in der Kunst des Bosporus, in Das Altertum, 5, 4 (1959), p. 91.

65 S.S. Bessonova, 'Ser'gi's izobrazbeniyem vladychitzy zverey iz skifskikh pogrebeniy IV $v$. do n.e. l'Earrings' with representations of the Mistress of the animals from the IV BC Scythian burials], in V.D. BARAN (ed.), Novye pamyatniki drevney i srednevekovoy khudozbestvennoy kul'tury [New monuments of ancient and mediaeval art], Kiev, 1982, p. 18-36. 
as well as rank-and-file worshippers. To judge by the surviving inscriptions from the fifth-first centuries $\mathrm{BC}$, Aphrodite received twelve dedications from both sides of the Bosporus (CIRB 7, 13, 17, 30, 31, 75, 971, 972, 1041, 1043, $1111,1234)$, much more than any other deity; even Apollo, the main god of the Ionian settlers, was honored in eight inscriptions only $(C I R B 6,10,25$, 974, 1037, 1038, 1039, 1044). Aphrodite had at least four sanctuaries: in Apatourum, Phanagoria, Panticapaeum and Cepi. Two of them, Apatourum

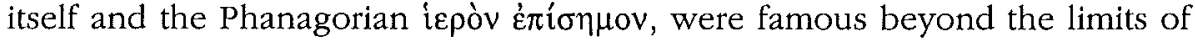
the Bosporan kingdom. Of other Greek gods, only Apollo had temples in three cities, Panticapaeum, Hermonassa and Phanagoria. The remaining gods either had one temple in Panticapaeum, or had no temples at all. The goddess, whose indigenous background showed through the conventional Greek attire, occupied the leading place in the pantheon of the Bosporus even before the cultural changes of the first centuries AD.

Department of History

Yulia US'TINOvA

Ben-Gurion University of the Negev

P.O.B. 653

BEER-SHEVA 84105 